\title{
NEOPTERIN, CELLULAR ADHESION MOLECULES AND MYELOPEROXIDASE IN PATIENTS WITH STABLE AND UNSTABLE ANGINA PECTORIS
}

\author{
Pēteris Tretjakovs*,**,****, Antra Jurka**,***, Inga Bormane**, Indra Miḳelsone**, \\ Dace Reihmane ${ }^{\star *}$, Gita Krieviña**, Iveta Marksa****, Karlīna Elksne*, \\ Jurijs Verbovenko*, ***, and Guntis Bahs*, *** \\ * Chair of Human Physiology and Biochemistry, Rīga Stradinš University, Dzirciema iela 16, Rĩga, LV-1007, LATVIA; \\ E-mail: tretjako@latnet.Iv \\ ** Institute of Experimental and Clinical Medicine, University of Latvia, O. Vācieša iela 4, Rīga, LV-1004, LATVIA \\ *** Rīga Eastern Clinical University Hospital, Hipokrāta iela 2, Rīga, LV-1038, LATVIA \\ **** Pauls Stradiṇš Clinical University Hospital, Pilsoṇu iela 13, Rĩga, LV-1002, LATVIA
}

Communicated by Valdis Pīrāgs

\begin{abstract}
Recent data indicate that the serum level of neopterin, a marker of inflammation and immune modulator secreted by monocytes/macrophages, is elevated in patients with acute coronary syndrome (ACS) and seems to be a prognostic marker for major cardiovascular events. Soluble cellular adhesion molecules (sCAMs) and myeloperoxidase (MPO) levels are also related to ACS. The aim of the present study was to evaluate differences in serum levels of neopterin, sCAMs and MPO between coronary artery disease and metabolic syndrome (CAD-MetS) patients with stable and unstable angina pectoris (SAP, UAP), and to clarify the relationships between neopterin and other biomarkers. The study included 60 patients with CAD-MetS who were classified into two groups, 30 patients with SAP and 30 patients with UAP. Twenty healthy subjects were selected as controls (C). Serum soluble vascular cell adhesion molecule-1 (sVCAM-1), intercellular cell adhesion molecule-1 (sICAM-1), sE-selectin and MPO levels were measured by Luminex $X M A P$ technology, and serum neopterin concentrations were measured by radioimmunoassay. Results: Serum levels of neopterin, MPO, sVCAM-1, sICAM-1, and sE-selectin were significantly higher in patients with UAP in comparison with the group of healthy controls $(P<0.05)$. Patients with SAP also had higher levels of these biomarkers than those in healthy controls $(P<0.05)$, except for sE-selectin. The biomarker level did not differ between the two patient groups, except for $M P O$, which was significantly higher in the USP group $(P<0.05)$. Neopterin was significantly correlated only with sVCAM-1 $(P<0.05)$. In conclusion, CAD-Met patients with SAP had more apparent raised levels of serum sICAM-1 and SVCAM-1, simultaneously with higher MPO and neopterin concentrations, in comparison to those in healthy subjects. However, UAP is also associated with more substantial changes in MPO and significantly increased sE-selectin levels. Neopterin concentration was had a close correlation only with SVCAM-1.
\end{abstract}

Key words: neopterin, cellular adhesion molecules, myeloperoxidase, angina pectoris, metabolic syndrome, coronary artery disease.

\section{INTRODUCTION}

Both endothelial cell activation and macrophage activation play significant roles in atherogenesis and atheromatous plaque vulnerability and may determine rapid coronary artery disease (CAD) progression (Zouridakis et al., 2004). Markers of systemic inflammation and macrophage activation, i.e., serum neopterin and C-reactive protein (CRP) levels, have been found to be associated with the presence of complex stenoses and the development of serious cardiovascular events (Avanzas et al., 2004a). There are data show- ing that serum levels of neopterin are elevated in patients with acute coronary syndromes (ACS), compared with those in stable angina pectoris (SAP) and healthy control subjects. In unstable angina pectoris (UAP), serum neopterin levels are associated with the presence of vulnerable coronary stenosis, multiple complex coronary lesions, and patient outcome. Serum neopterin is an independent predictor of major adverse coronary events in patients with chronic SAP and as a marker of macrophage activation it may be useful for risk stratification in patients with chronic SAP (Avanzas et al., 2005). 
Although studies have reported an association between neopterin and the extent of atherosclerosis, serum neopterin levels are not correlated with severity or extent of CAD (Schumacher et al., 1997; Avanzas et al., 2005), which suggests that neopterin may be a marker of inflammatory coronary disease activity, rather than a measure of the anatomical extent of the coronary atheromatous process (Avanzas et al., 2005). Neopterin stimulates nuclear factor-kB translocation to the nucleus (Wirleitner et al., 1997), promoting the expression of proinflammatory genes, adhesion molecules, tissue factor, and other substances implicated in the inflammatory processes that take place within the arterial wall in atherogenesis and atheromatous plaque disruption. Avanzas et al. have shown that serum neopterin concentrations are associated with the development of adverse cardiovascular events in patients with SAP. This association is independent of the severity of CAD. Neopterin may thus be a useful marker of risk of future coronary events in these patients (Avanzas et al., 2005).

Soluble cellular adhesion molecules (sCAMs) have also been suggested to represent an important factor in atheromatous plaque disruption and the occurrence of ACS (Ridker et al., 1998). The expression of soluble vascular cell adhesion molecule-1 (sVCAM-1) and intercellular cell adhesion molecule-1 (sICAM-1) is increased in response to inflammatory cytokines or oxidised low-density lipoprotein (LDL). Because these molecules are also expressed on a variety of cell types, including smooth muscle cells or monocytes, they are not endothelial cell specific (Constans et al., 2006). sICAM-1 and sVCAM-1 have been detected in atherosclerotic plaques. Both sICAM-1 and sVCAM-1 levels are higher in variant angina pectoris patients than in healthy controls (Miwa et al., 1997). Metabolic syndrome (MetS), which is frequently present in CAD patients, is considered a state of chronic inflammation closely associated with endothelial dysfunction causing an increased incidence of ischemic cardiovascular events and high mortality. Low-grade inflammation is manifested in patients with increased plasma levels of SVCAM-1, sICAM-1 and endothelial-leukocyte adhesion molecule-1 (sE-selectin) (Gonzalez and Selwyn, 2003), which are correlated with inflammatory markers e.g., CRP, tumour necrosis factor-alpha (TNF- $\alpha$ ), interleukin (IL)-6, and IL-1 (Ruotsalainen et al., 1998).

Despite the fact that many studies have reported cytokine imbalance in ACS (Alam et al., 2004) there is a lack of evidence of a significant correlation between neopterin and cytokines, including sCAMs. Data of recent studies confirm the pivotal role of sCAMs in the development of CAD, but it is still unclear which type of sCAMs has a closer relationship to acute coronary syndrome.

It is known that myeloperoxidase (MPO) is a heme protein produced by activated neutrophils, monocytes, and tissue macrophages and catalyses the modification of LDL, which is a critical step in atherogenesis (Zhang et al., 2001). Several studies have suggested that there is an association between MPO level and CAD (Zhang et al., 2001). In a prospective study of patients presenting to the emergency department with chest pain, elevated MPO levels identified patients with undetectable troponin $\mathrm{T}$ levels, who were at increased risk of myocardial infarction (MI) during their hospital stay or after discharge (Brennan et al., 2003). MPO independently predicts CAD (Nicholls and Hazen, 2005) and may participate in plaque vulnerability and instability process (Roman et al., 2010), but there are only a small number of comparative studies of MPO and other cytokines that indicate endothelial activity, in patients with SAP and UAP.

The purpose of the present study was to evaluate alterations in serum levels of neopterin, sCAMs and MPO in coronary artery disease patients with metabolic syndrome (CADMetS), who were diagnosed with either SAP or UAP, and to clarify relationships between neopterin and other biomarkers.

\section{MATERIALS AND METHODS}

Subjects. CAD-Met patients with dyslipidemia were classified into two groups: 30 patients with SAP, and 30 patients with UAP. 20 healthy subjects were selected as controls (C). The study groups were matched for age, sex and number of smokers, and the patient groups also for body mass index (BMI), type-2 diabetes mellitus (T2DM) and hypertension. Demographic and clinical data of the study groups are presented in Table 1.

The diagnosis of CAD was substantiated by coronary angiography. Digital coronary angiography was performed by means of a GE Medical System X-ray digital angiography system. Results of coronary angiography were accepted as positive if stenosis $50 \%$ of at least one of the three main epicardial branches of coronary arteries was detected. In UAP patients, coronary angiography was performed at the emergency department, and the diagnosis of CAD in SAP patients was angiographycally confirmed at least six months earlier. SAP was defined as angina pectoris symptoms stable for 3 months. We did not include patients with previous history of coronary artery bypass graft surgery, myocardial infarction (MI) (as defined by standard World Health Organization criteria), or clinically significant valve heart disease. Previous history of UAP (defined according to Braunwald's classification (Braunwald, 1989) was also assessed in every patient. MetS was diagnosed according to the International Diabetes Foundation criteria with specific reference to the European population (Alberti et al., 2005).

T2DM was defined as a reported history of diabetes and treated with antidiabetic drugs. Duration of T2DM was $5 \pm$ 3 years and glycated hemoglobin $\mathrm{HbA}_{1 \mathrm{c}}$ in diabetics was less than $7.5 \%$. Diabetics were not undergoing insulin therapy and lacked pronounced diabetic complications. Patients who had evidence of peripheral vascular disease or cerebral ischemia were not included. Other exclusion factors were acute inflammatory condition or chronic inflammatory states, such as rheumatoid arthritis, systemic lupus erythematosus, vasculitis, inflammatory bowel disease, renal or 


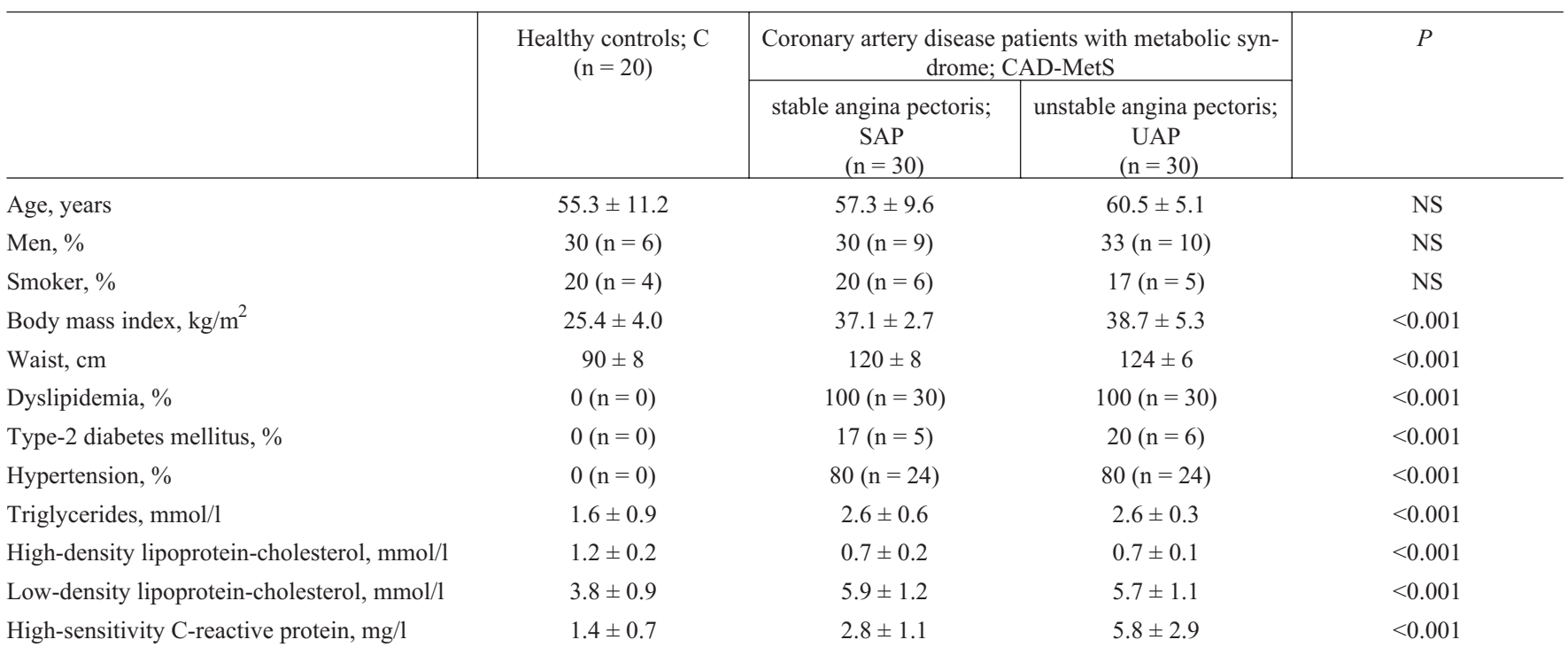

Data are expressed as number (n), or means $\pm \mathrm{SD}$.

$\mathrm{NS}=$ not significant $(P>0.05$ compared to all group $)$

liver diseases, or malignancies and other diseases known to be associated with significant changes of cytokines, including surgery or trauma within the preceding 30 days. We did not include patients who were taking COX-2 inhibitors, nonsteroidal antiinflammatory agents or corticosteroids, or had been taking them within the preceding 30 days. All subjects gave their informed consent to the protocol, which was approved by the local Medical Ethics Committee of the University of Latvia for Biomedical Research.

Measurements. Blood samples $(5 \mathrm{ml})$ for the determination of cytokines were collected after a 12-h fast and allowed to coagulate for 20 to $30 \mathrm{~min}$ at room temperature. Sera were separated by centrifugation at $4 \mathrm{C}$ for $20 \mathrm{~min}$ at $1600 \mathrm{x} \mathrm{g}$. All specimens were immediately aliquoted, frozen, and stored at $-80^{\circ}$. sVCAM-1, sICAM-1, endothelial-leukocyte adhesion molecule-1 (sE-selectin), and MPO concentrations were measured by Luminex xMAP technology (Millipore $\mathrm{GmbH}$ ), and serum neopterin levels were measured by commercially available radioimmunoassay (Brahms Diagnostica $\mathrm{GmbH}$ ). CRP concentrations were measured with a highsensitivity Immulite ELISA immunoassay (DPC, Gwynedd Ltd.). Fasting concentrations of lipids, glucose, and other routine blood biomarkers were analysed by standard methods.

Statistical analysis. After testing the normality of data distribution with the Kolmogorov-Smirnov test (neopterin and all other biomarkers had a normal distribution), statistical differences between two groups were analysed by a twosided unpaired Student's t test and differences between three groups assessed by Kruskal-Wallis test. Data were recorded as the means $\pm \mathrm{SD}$ and a two-tailed value of $P<0.05$ was considered to be significant. Correlation analyses were performed using one-factor linear regression analysis. All analyses were performed using STATISTICA 7 software (StatSoft Inc., USA).

\section{RESULTS}

Both patient groups demonstrated significantly higher neopterin levels than in the group of healthy controls (C: $4.79 \pm$ 0.76 , SAP: $6.81 \pm 3.26$, UAP: $6.64 \pm 3.55 \mathrm{nmol} / 1, P<0.05)$, while the level of neopterin in the UAP group was not higher than that in the group of SAP patients (Fig. 1).

Serum levels of sVCAM-1, sICAM-1, and sE-selectin in patients with UAP $(P<0.05)$ were significantly higher in comparison with those in the control group $(P<0.01)$, but were not different from those in the SAP group, except for

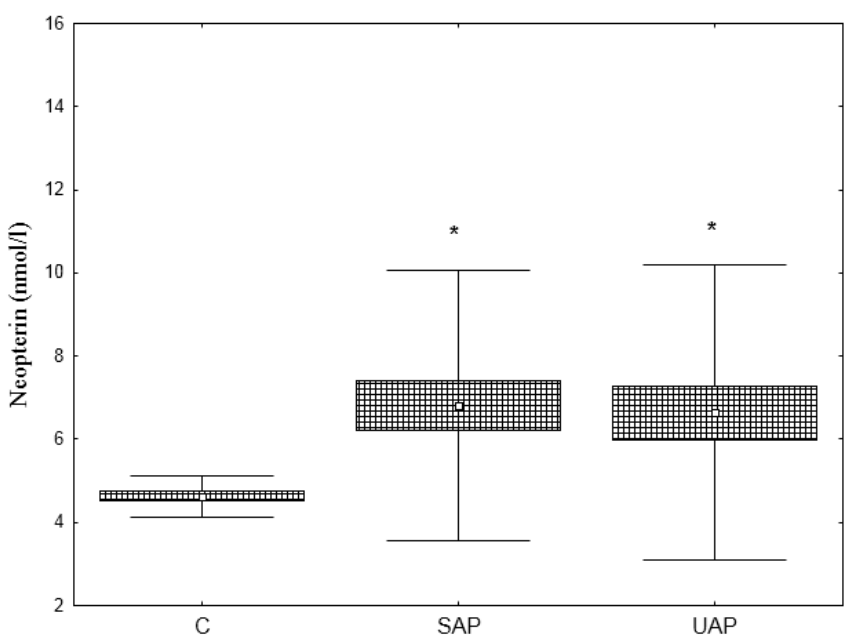

Fig. 1. Neopterin level in stable (SAP) and unstable angina pectoris (UAP) patients with coronary artery disease and metabolic syndrome; and healthy subjects $(C)$. Data are expressed as mean $\pm \mathrm{SD} .{ }^{*} P<0.05$ vs. controls. 


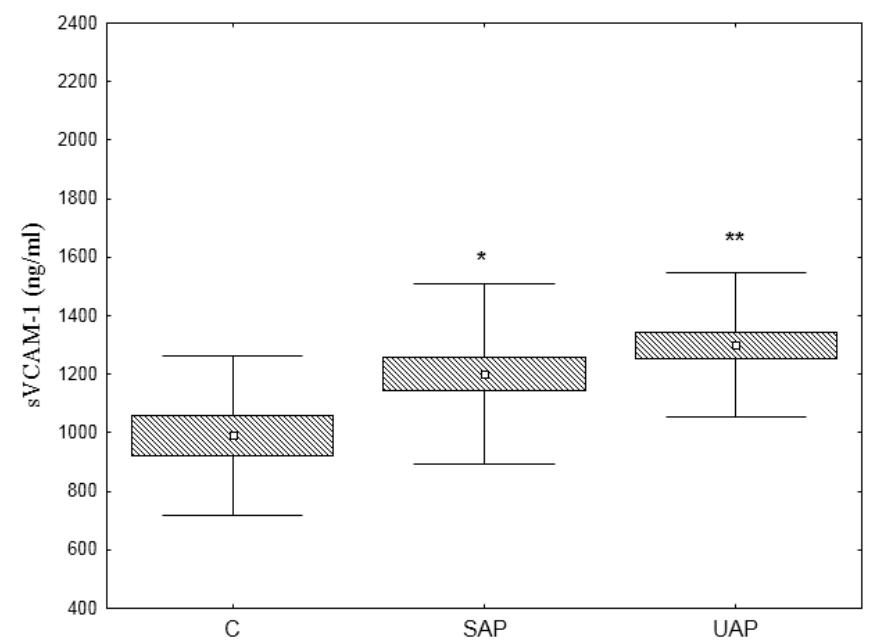

Fig. 2. Soluble vascular cell adhesion molecule-1 (sVCAM-1) level in stable (SAP) and unstable angina pectoris (UAP) patients with coronary artery disease and metabolic syndrome; and healthy subjects (C). Data are expressed as mean $\pm \mathrm{SD}$. ${ }^{*} P<0.05,{ }^{* *} P<0.01$ vs. controls.

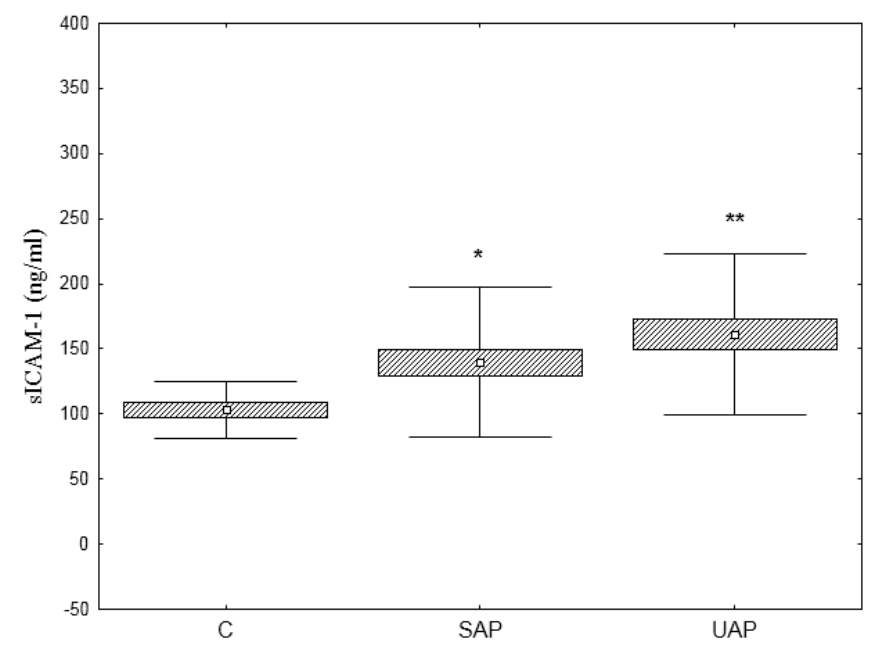

Fig. 3. Soluble intercellular cell adhesion molecule-1 (sICAM-1) level in stable (SAP) and unstable angina pectoris (UAP) patients with coronary artery disease and metabolic syndrome; and healthy subjects (C). Data are expressed as mean $\pm \mathrm{SD}$. $* P<0.05, * * P<0.001$ vs. controls.

the level of sE-selectin, which in this group of patients did not differ from that in healthy controls (Figs. 2, 3 and 4).

A significant increase in serum MPO concentrations was observed in both patient groups $(P<0.001)$, and the MPO level in the UAP group was higher compared to that of the SAP group (SAP: $137.5 \pm 79.9$ vs. UAP: $221.1 \pm 196.9$ $\mathrm{ng} / \mathrm{ml}, P<0.05$ ) (Fig. 5).

Serum neopterin levels were significantly correlated with sVCAM-1 concentrations $(\mathrm{r}=0.28, P<0.05)$ (Fig. 6), but no correlations were established with other biomarkers.

\section{DISCUSSION}

Inflammation is a crucial factor in atherogenesis and CAD progression and there is evidence that molecules such as

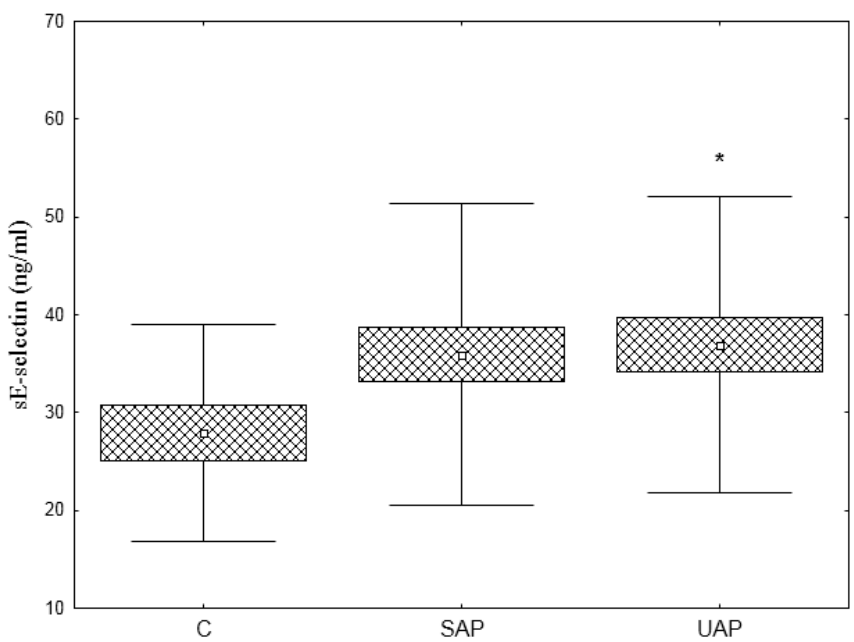

Fig. 4. Soluble endothelial-leukocyte adhesion molecule-1 (sE-selectin) level in stable (SAP) and unstable angina pectoris (UAP) patients with coronary artery disease and metabolic syndrome; and healthy subjects (C). Data are expressed as mean $\pm \mathrm{SD} .{ }^{*} P<0.05$ vs. controls.

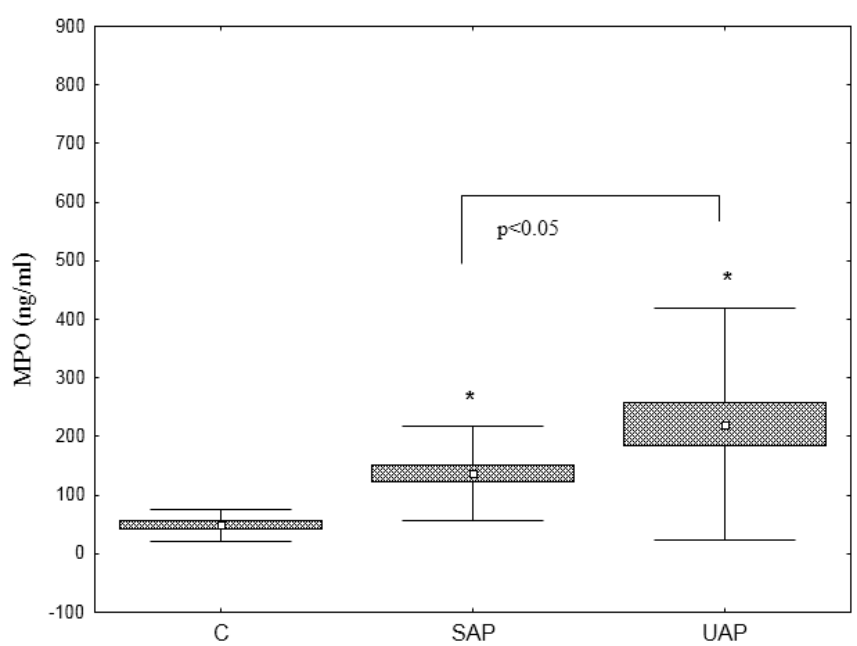

Fig. 5. Myeloperoxidase (MPO) level in stable (SAP) and unstable angina pectoris (UAP) patients with coronary artery disease and metabolic syndrome; and healthy subjects (C). Data are expressed as mean $\pm \mathrm{SD}$. ${ }^{*} P<$ 0.0001 vs. controls.

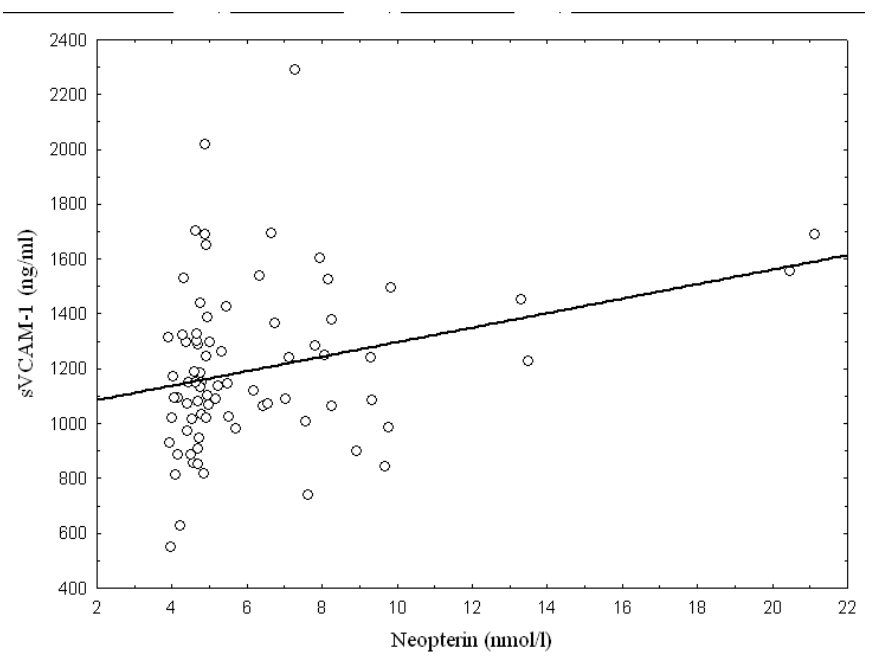

Fig. 6. Correlation of neopterin and soluble vascular cell adhesion molecule-1 (sVCAM-1) levels in total clinical material $(\mathrm{r}=0.28, P<0.05)$. 
CRP, neopterin, and sCAMs may not be just markers of inflammation and cardiovascular risk, but that they also likely play a pathogenic role in atheromatous plaque vulnerability and rapid coronary stenosis progression (Burke et al., 2002).

The results of the present study indicate that CAD-MetS patients with SAP have higher serum levels than do healthy controls regarding two circulating sCAMs: sICAM-1 and sVCAM-1, and also significantly higher serum neopterin and MPO levels. UAP was associated with significantly elevated sE-selectin concentration and the increase in MPO was more pronounced in UAP than SAP patients. The study showed a significant correlation between serum neopterin and sVCAM-1. However, no correlation was found between neopterin and other biomarkers.

Neopterin, a molecule secreted by activated macrophages on stimulation by interferon-gamma (Huber et al., 1984), has previously been reported to be elevated in the serum of patients with ACS, compared with patients with stable forms of $\mathrm{CAD}$, and correlated with increased cardiovascular risk (Avanzas et al., 2004b). There is evidence that increased neopterin levels are an independent predictor of 180-day adverse cardiac events in patients with ACS (Kaski et al., 2008) and that neopterin may thus be clinically useful for patient risk stratification (Estévez-Loureiro et al., 2009). Although our data showed that serum neopterin levels in CAD-MetS were significantly higher than those in healthy controls, the increase was similar in UAP and SAP. Neopterin is considered to be a pathogenic factor in the development of cardiac dysfunction in chronic disease states with high neopterin levels secondary to activation of the immune system (Balogh et al., 2005). Neopterin is a sensitive indicator for cellular immune activation. Furthermore, reactive oxygen species are produced in cases of immune activation and inflammation (Murr et al., 2009). Previous studies indicate that neopterin exerts a direct effect on human coronary artery endothelial cells by promoting sCAMs and tissue factor expression and support the hypothesis that neopterin, besides representing a marker of inflammation, might be an effector molecule able to induce a pro-atherothrombotic phenotype in cells of the coronary circulation (Cirillo et al., 2006).

In recent years, special attention has been paid to the potential value of sCAMs as biomarkers for CAD risk (Blankenberg et al., 2001). sCAMs may be important in atherosclerosis, inasmuch as they facilitate the immigration of leukocytes into the vessel wall (van der Meer et al., 2002). However, reports on sCAMs and atherosclerosis are not consistent. Several studies have reported significant associations of sICAM-1 (Hwang et al., 1997), sVCAM-1 (Peter et al., 1997) or both sCAMs (Blankenberg et al. 2001) with measures of atherosclerosis. Our findings support the notion (Kressel et al., 2009) that adhesion molecules are excellent markers of CAD risk, especially in metabolic syndrome patients. Nevertheless, clinical data regarding these soluble sCAMs forms are controversial. For example, there are reports that support the notion that inflammation-related en- dothelial cell activation is reflected mainly by increased sICAM-1 levels (Zouridakis et al., 2004). Other studies, on the contrary, have shown that SVCAM-1 is more closely related to ACS than SICAM-1. UAP is characterised by significant elevation of serum SVCAM-1 levels, which seems to be related to enhanced platelet and leukocyte activation (Mizia-Stec et al., 2002). It has been suggested that SVCAM-1, but not sICAM-1, may serve as a marker of CAD in patients with SAP (Eschen et al., 2005), and that sVCAM-1 may represent the persistent existence of coronary endothelial dysfunction and may be an index that predicts progression of coronary atherosclerosis. These findings can be explained by the different roles of sICAM-1 and sVCAM-1 in the progression of atherosclerosis. sICAM-1 appears to be a general marker of a pro-inflammatory status, whereas SVCAM-1 emerges as a predictor for future cardio-cardiovascular events in patients with pre-existing disease (Blankenberg et al., 2003). Our data showed that SAP and USP in CAD-MetS patients were associated with equally significant elevation of sVCAM-1 and sICAM-1. sE-selectin is specific for the endothelium and is increased in CAD and diabetes mellitus (Constans and Conri, 2006). A circulating form of sE-selectin may be released by enzymatic cleavage or may result from shedding of damaged or activated endothelial cells (Pigott et al., 1992). Therefore, plasma sE-selectin concentration may be a marker of endothelial cell damage or activation. In most studies, sEselectin levels have been found to be increased in patients with UAP or acute MI when compared to healthy controls (Mizia-Stec et al., 2002). However, the role of sCAMs in risk stratification in patients with CAD is not established, as the results on predicting cardiovascular risk are rather confusing (Zakynthinos and Pappa, 2009). An association between obesity in MetS patients and the expression of sCAMs has also been demonstrated. This suggests that obesity is involved in the development of endothelial dysfunction. Studies on the effects of weight loss suggest that endothelial dysfunction caused by obesity is reversible. Mechanisms that may explain these relationships include increased oxidative stress to the cardiovascular system in overweight patients, increased production of inflammatory markers by adipocytes, and metabolic stimuli such as the effect of insulin on the endothelium (Schram and Stehouwer, 2005). sCAMs may play an important role in the development of MetS and T2DM, as well as in their cardiovascular complications. Strong evidence exists that an increased level of sCAMs reflects an alteration of endothelial function, which may have pathophysiological consequences.

Inflammation and oxidative stress are associated with atherosclerosis. MPO is linked to both inflammation and oxidative stress by its location in leukocytes and its role in catalysing the formation of oxidising agents. Recent evidence suggests that MPO activity precipitates atherogenesis. Measurement of MPO in plasma may therefore contribute to $\mathrm{CAD}$ risk stratification. Increasing evidence suggests that MPO is causally linked to atherosclerosis and that its measurement may improve CAD risk estimation (Schindhelm et al., 2009). MPO seems to contribute directly to the patho- 
genesis of ACS. The current data underscore the role of MPO as a diagnostic marker in acute coronary disease; however, the additive information derived from MPO is restricted to patients presenting in the early phase of symptom onset (Rudolph et al., 2010). Oxidative stress participates in all stages of cardiovascular disease, from lipoprotein modification to plaque rupture, and biomarkers of oxidative stress predict development of CAD (Heslop et al., 2010). Increased plasma levels of MPO independently predict endothelial dysfunction and CAD (Nicholls and Hazen, 2005), even after adjusting for traditional risk factors or CRP. In subjects presenting with acute coronary events, the serum MPO level is a strong predictor of adverse cardiac outcome (Baldus et al., 2003). Taken together, these findings suggest a distinct role of the inflammatory markers studied in the pathophysiology of CAD (Roman et al., 2010). Emerging paradigms shift the focus from treating flow-limiting lesions and classic risk factors to a more integrated approach that includes prevention and identification of plaque vulnerability and modifiable inflammatory triggers and mediators (Alam et al., 2004).

Our findings show that CAD-Met patients with SAP demonstrate elevated serum SICAM-1 and sVCAM-1 concentrations and have higher MPO and neopterin levels, compared to those in healthy subjects. The presence of UAP in CADMet patients is also associated with a more pronounced increase in MPO concentrations and significantly elevated sE-selectin levels. Despite sICAM-1 and sVCAM-1 levels being higher in angina pectoris patients than in healthy controls, neopterin has a close correlation only with sVCAM-1. This shows the implication of neopterin in the development of adverse cardiovascular events (UAP) by promoting elevation of sVCAM-1, which leads us to the conclusion that both neopterin and SVCAM may be useful markers for predicting the risk of future coronary events in UAP patients.

\section{ACKNOWLEDGEMENTS}

This study was supported in part by European Economic Area grant EEZ08AP-5/2 and by grant No. 2010.10-4/ VPP-4/5 of the framework of the Latvian National Programme. The authors wish to express their gratitude to prof. Dietmar Fuchs from Medical University of Innsbruck for his invaluable help in the determination of neopterin levels.

\section{REFERENCES}

Alam, S.E., Nasser, S.S., Fernainy, K.E., Habib, A.A., Badr, K.F. (2004). Cytokine imbalance in acute coronary syndrome. Curr. Opin. Pharmacol., 4(2), 166-170.

Alberti, K.G., Zimet, P., Shaw, J. (2005). The metabolic syndrome - a new worldwide definition. Lancet, 366(9491), 1059-1062.

Avanzas, P., Arroyo-Espliguero, R., Coskn-Sales, J., Aldama, G., Pizzi, C., Quiles, J., Kaski, J.C. (2004a). Markers of inflammation and multiple complex stenoses (pancoronary plaque vulnerability) in patients with non-ST segment elevation acute coronary syndromes. Heart, 90, 847-852.

Avanzas, P., Arroyo-Espliguero, R., Cosin-Sales, J., Quiles, J., Zouridakis, E., Kaski, J.C. (2004b). Prognostic value of neopterin levels in treated pa- tients with hypertension and chest pain but without obstructive coronary artery disease. Amer. J. Cardiol., 93, 627-629.

Avanzas, P., Arroyo-Espliguero, R., Quiles, J., Roy, D., Kaski, J.C. (2005). Elevated serum neopterin predicts future adverse cardiac events in patients with chronic stable angina pectoris. Eur. Heart. J., 26(5), 457-463.

Baldus S., Heeschen C., Meinertz T., Zeiher A.M., Eiserich J.P., Munzel T., Simoons M.L., Hamm C.Q., CAPTURE Investigators. (2003). Myeloperoxidase serum levels predict risk in patients with acute coronary syndromes. Circulation, 108, 1440-1445.

Balogh A., Mittermayr M., Schlager A., Balogh D., Schobersberger W., Fuchs D., Margreiter J. (2005). Mechanism of neopterin-induced myocardial dysfunction in the isolated perfused rat heart. Biochim. Biophys. Acta, 1724(1-2), 17-22.

Blankenberg, S., Barbaux, S., Tiret, L. (2003) Adhesion molecules and atherosclerosis. Atherosclerosis, 170, 191-203.

Blankenberg, S., Rupprecht, H.J., Bickel, C. (2001). Circulating cell adhesion molecules and death in patients with coronary artery disease. Circulation, 104, 1336-1342.

Braunwald, E. (1989). Unstable angina: A classification. Circulation, 80, 410-414.

Brennan M.L., Penn M.S., van Lente F., Nambi V., Shishehbor M.H., Aviles R.J., Goormastic M., Pepoy M.L., McErlean, E.S., Topol, E.J., Nissen, S.E., Hazen, S.L. (2003) Prognostic value of myeloperoxydase in patients with chest pain. N. Engl. J. Med., 349, 1595-1604.

Burke, A.P., Tracy, R.P., Kolodgie, F., Malcom, G.T., Zieske, A., Kutys, R., Pestaner, J., Smialek, J., Virmani, R. (2002). Elevated C-reactive protein values and atherosclerosis in sudden coronary death: Association with different pathologies. Circulation, 105, 2019-2023.

Cirillo, P., Pacileo, M., de Rosa, S., Calabrn, P., Gargiulo, A., Angri, V., Granato-Corigliano, F., Fiorentino, I., Prevete, N., de Palma, R., Mauro, C., Leonardi, A., Chiariello, M. (2006). Neopterin induces pro-atherothrombotic phenotype in human coronary endothelial cells. J. Thromb. Haemost., 4(10), 2248-2255.

Constans, J., Conri, C. (2006). Circulating markers of endothelial function in cardiovascular disease. Clin. Chim. Acta, 368(1-2), 33-47.

Eschen, O., Christensen, J.H., Toft, E., Schmidt, E.B. (2005). Soluble adhesion molecules and marine n-3 fatty acids in patients referred for coronary angiography. Atherosclerosis, 180(2), 327-331.

Estévez-Loureiro, R., Recio-Mayoral, A., Sieira-Rodrķguez-Moret, J.A., Trallero-Araguįs, E., Kaski, J.C. (2009). Neopterin levels and left ventricular dysfunction in patients with chronic stable angina pectoris. Atherosclerosis, 207(2), 514-518.

Gonzalez, M.A., Selwyn, A.P. (2003). Endothelial function, inflammation, and prognosis in cardiovascular disease. Amer. J. Med., 115(Suppl. 8A), 99S-106S

Heslop, C.L., Frohlich, J.J., Hill, J.S. (2010). Myeloperoxidase and C-reactive protein have combined utility for long-term prediction of cardiovascular mortality after coronary angiography. J. Amer. Coll. Cardiol., 55(11), 1102-1109.

Huber, C., Batchelor, J.R., Fuchs, D., Hausen, A., Lang, A., Niederwieser, D., Reibnegger, G., Swetly, P., Troppmair, J., Wachter, H. (1984) Immune response-associated production of neopterin: Release from macrophages primarily under control of interferon-gamma. J. Exp. Med., 160, 310-316.

Hwang, S.J,, Ballantyne, C.M., Sharrett, A.R, (1997). Circulating adhesion molecules VCAM-1, ICAM-1, and E-selectin in carotid atherosclerosis and incident coronary heart disease cases: The atherosclerosis risk in communities (ARIC) study. Circulation, 96, 4219-4225.

Kaski, J.C., Consuegra-Sanchez, L., Fernandez-Berges, D.J., CruzFernandez, J.M., Garcia-Moll, X., Marrugat, J., Mostaza, J., Toro-Cebada, R., Gonzillez-Juanatey, J.R., Guzmįn-Martḳnez, G.; SIESTA Investigators. (2008). Elevated serum neopterin levels and adverse cardiac events at 6 months follow-up in Mediterranean patients with non-ST-segment elevation acute coronary syndrome. Atherosclerosis, 201(1), 176-183. 
Kressel, G., Trunz, B., Bub, A., Hülsmann, O. (2009). Systemic and vascular markers of inflammation in relation to metabolic syndrome and insulin resistance in adults with elevated atherosclerosis risk. Atherosclerosis, 202(1). 263-271

Miwa, K., Igawa, A., Inoue, H. (1997). Soluble E-selectin, ICAM-1 and VCAM-1 levels in systemic and coronary circulation in patients with variant angina. Cardiovasc. Res., 36, 37-44.

Mizia-Stec, K., Zahorska-Markiewicz, B., Mandecki, T., Janowska, J., Szulc, A., Jastrzebska-Maj, E. (2002). Serum levels of selected adhesion molecules in patients with coronary artery disease. Int. J. Cardiol., 83(2), $143-150$.

Murr, C., Winklhofer-Roob, B.M., Schroecksnadel, K., Maritschnegg, M., Mangge, H., Böhm, B.O., Winkelmann, B.R., März, W., Fuchs, D. (2009). Inverse association between serum concentrations of neopterin and antioxidants in patients with and without angiographic coronary artery disease. Atherosclerosis, 202(2), 543-549.

Nicholls, S., Hazen, S. (2005). Myeloperoxidase and cardiovascular disease. Arterioscler. Thromb. Vasc. Biol., 25, 1102-1111.

Peter, K., Nawroth, P., Conradt, C. (1997). Circulating vascular cell adhesion molecule-1 correlates with the extent of human atherosclerosis in contrast to circulating intercellular adhesion molecule-1, E-selectin, P-selectin, and thrombomodulin. Arterioscler. Thromb. Vasc. Biol., 17, 505-512.

Pigo, R., Dillon, L.P., Hemingway, I.H., Gearing, A.J. (1992). Soluble forms of Eselectin, ICAM-1 and VCAM-1 are present in the supernatants of cytokine activated cultured endothelial cells. Biochem. Biophys. Res. Commun., 187, 584-589.

Ridker, P.M., Hennekens, C.H., Roitman-Johnson, B., Stampfer, M.J., Allen, J. (1998). Plasma concentration of soluble intercellular adhesion molecule 1 and risks of future myocardial infarction in apparently healthy men. Lancet, 351, 88-92.

Roman, R.M., Camargo, P.V., Borges, F.K., Rossini, A.P., Polanczyk, C.A. (2010) Prognostic value of myeloperoxidase in coronary artery disease: Comparison of unstable and stable angina patients. Coron. Artery Dis., 21(3), 129-136.
Roman, R.M., Camargo, P.V., Borges, F.K., Rossini, A.P., Polanczyk, C.A. (2010). Prognostic value of myeloperoxidase in coronary artery disease: Comparison of unstable and stable angina patients. Coron. Artery. Dis., 21(3), 129-136.

Rudolph, V., Goldmann B.U., Bös C., Rudolph T.K., Klinke A., Friedrichs K., Lau D., Wegscheider K., Haddad, M., Meinertz, T., Baldus, S. (2010). Diagnostic value of MPO plasma levels in patients admitted for suspected myocardial infarction. Int. J. Cardiol., [Epub ahead of print].

Ruotsalainen, E., Vauhkonen, I., Salmenniemi, U., Pihlajamäki, J. (2008) Markers of endothelial dysfunction and low-grade inflammation are associated in the offspring of type 2 diabetic subjects. Atherosclerosis, 197(1), 271-277.

Schindhelm, R.K., van der Zwan, LP., Teerlink T., Scheffer. P.G. (2009). Myeloperoxidase: A useful biomarker for cardiovascular disease risk stratification? Clin Chem., 55(8), 1462-1470.

Schumacher, M., Halwachs, G., Tatzber, F., Fruhwald, F.M., Zweiker, R., Watzinger, N. (1997). Increased neopterin in patients with chronic and acute coronary syndromes. J. Amer. Coll. Cardiol., 30, 703-707.

van der Meer, I., de Maat, M.P., Bots, M.L. (2002).. Inflammatory mediators and cell adhesion molecules as indicators of severity of atherosclerosis: The Rotterdam study. Arterioscler. Thromb. Vasc. Biol., 22, 838-842.

Wirleitner, B., Baier-Bitterlich, G., Hoffmann, G., Schobersberger, W., Wachter, H., Fuchs, D. (1997) Neopterin derivatives to activate NF-kappa B. Free Radic. Biol. Med., 23, 177-179.

Zakynthinos, E., Pappa, N. (2009). Inflammatory biomarkers in coronary artery disease. J. Cardiol., 53(3), 317-333.

Zhang, R., Brennan, M.L., Fu, X., Aviles, R.J., Pearce, G.L., Penn, M.S., Topol E.J., Sprecher, D.L., Hazen, S.L. (2001). Association between myeloperoxidase levels and risk of coronary artery disease. J. Amer. Med. Assoc., 286, 2136-2142.

Zouridakis, E., Avanzas, P., Arroyo-Espliguero, R., Fredericks, S., Kaski, J.C. (2004). Markers of inflammation and rapid coronary artery disease progression in patients with stable angina pectoris. Circulation, 110, 1747-1753.

Received 2 February 2011

\section{NEOPTERĪNS, ŠŪNU ADHĒZIJAS MOLEKULAS UN MIELOPEROKSIDĀZE PACIENTIEM AR STABILU UN NESTABILU STENOKARDIJU}

Mūsdienu pētījumi liecina, ka pacientiem ar akūtu koronāro sindromu (ACS) ir palielināta neopterīna koncentrācija asins serumā un tā spēj kalpot kā prognostisks biomarkieris kardiovaskulāriem notikumiem. Seruma šḳīstošo šūnu adhēzijas molekulu (sCAMs) un mieloperoksidāzes (MPO) koncentrācijas palielināšanās arī ir saistīta ar ACS. Šī pētījuma mērkiis bija novērtēt atškikirības neopterīna, sCAMs un MPO seruma koncentrāciju atškirīības koronārās sirds slimības un metabolā sindroma pacientiem (CAD-MetS) ar stabilu un nestabilu stenokardiju (SAP, UAP), kā arī noskaidrot neopterīna saistību ar minētajiem biomarkieriem. Pētījumā tika iesaistîti 60 CAD-MetS pacienti, no kuriem 30 bija ar SAP un 30 ar UAP. 20 veseli voluntieri tika ieklauti kontroles grupā (C). Seruma šķ̄istošo vaskulāro šūnu adhēzijas molekulu-1 (sVCAM-1), intracelulāro šūnu adhēzijas molekulu-1(sICAM-1), šķīstošā E-selektīna (sE-selectin) un MPO koncentrācijas tika noteiktas ar Luminex xMAP tehnoloǵiju, bet seruma neopterīna koncentrācija - radioimunologíiski. Seruma neopterīna, MPO, sVCAM-1, sICAM-1 un sE-selectin koncentrācijas bija statistiski ticami augstākas pacientiem ar UAP, salīdzinot ar C grupu $(P<0.05)$. Pacientiem ar SAP arī bija būtiski augstāka minēto biomarkieru koncentrācija serumā nekā veseliem voluntieriem, izṇemot sE-selectin koncentrācijas, kas neatšḳīās. Pētījuma biomarķieru koncentrācijas neatšḳ̄īās starp pacientu grupām, izṇemot MPO koncentrāciju, kas bija būtiski lielāka USP pacientu grupā ( $P<0.05)$. Neopterīna koncentrācijas būtiski korelēja tikai ar sVCAM-1 koncentrācijām $(P<0.05)$. Tādējādi CAD-MetS pacientiem ar SAP ir būtiskāk izteikts sVCAM-1 un sICAM-1 seruma koncentrāciju palielinājums, vienlaikus, lielākas neopterīna un MPO koncentrācijas, bet UAP saistīts ar vēl būtiskāku MPO un sE-selectin koncentrāciju palielināšanos, salīdzinot ar veseliem voluntieriem. Seruma neopterīnam ir cieša korelācija tikai ar sVCAM-1. 